\title{
LINKING HISTORICAL RESEARCH WITH RESTORATION ECOLOGY IN THE FLOODPLAIN LANDSCAPE
CASE STUDY: LANDSCAPE-ECOLOGICAL STUDY (CZECH REPUBLIC) AND MANAGEMENT PLAN OF THE TOVAČOV LAKES
}

\author{
IVO MACHAR ${ }^{1}$, MICHAL SERVUS $^{2}$ \\ ${ }^{1}$ Palacky University, Department of Biology, Faculty of Education, Žižkovo nám.5, 77140 \\ Olomouc, Czech Republic, ivo.machar@upol.cz \\ ${ }^{2}$ Agency for Nature Conservation and Landscape Protection, Husova 906, 78401 Litovel, \\ Czech Republic, michal.servus@nature.cz
}

Received: $19^{\text {th }}$ March 2010, Accepted: $20^{\text {th }}$ May 2010

\begin{abstract}
This article deals with a conflict between the exploitation of mineral resources and nature protection at the study area of gravel mining lakes in the floodplain of the Morava River near the town of Tovačov (central Moravia, Czech Republic), and presents a concept of the compromise solution to this conflict, based on linking historical research with application of restoration ecology.
\end{abstract}

Key words - Floodplain, historical changes in landscape, Natura 2000, restoration ecology.

\section{INTRODUCTION}

Restoration ecology is a new field of science that formed in the 1980s with the aim to restore human-impacted ecosystems (Hobbs \& Harris 2001; Prach 2008). Restoration ecology builds upon the key concept of ecological restoration, which is a process of ecosystem restoration (De Moral \& Walker 2007). A holistic approach to the structure and functions of the ecosystems is fundamental in restoration ecology of wetlands and rivers (Ripl et al. 1994). Restoration ecology in river and floodplain ecosystems (Darby \& Sear 2008) is based also on an integrated approach to river basins (examples in Eiseltová 1995) and respect for the dynamics of natural fluvial processes (Muhar et al. 1995; Šterrba et al. 2008).

Understanding the historical context of the creation and formation of landscape is of a particular importance for the management needs of European floodplains (Trémolliéres \& Schnitzler 2007), because this type of landscape has formed over a long period of time under the direct and powerful influence of human (see Lipský 2008; Klimo et al. 2008),

The creation of the European network Natura 2000 in the Czech Republic (Roth 2009) sometimes brings paradoxical situations: Some proposed Natura 2000 sites can be designated in damaged areas due to the occurrence of some specially protected species. Such example is the area of gravel mining lakes in the floodplain of the Morava River near Tovačov (central Moravia, Czech Republic). Using unpublished data (Servus et al. 2008), this study describes the conflict of interests between the exploitation of mineral resources 
and nature conservation in this locality, and presents a concept of the compromise solution, based on linking historical research with application of some restoration ecology principles.

\section{METHODS AND MATERIALS}

\section{Area of study}

The area of study of the Tovačov Lakes in the floodplain of the Morava River in central Moravia was created by gravel mining in originally arable land during the $20^{\text {th }}$ century. The area of study of the Tovačov Lakes covers about 400 ha (Fig. 1), it borders with the town of Tovačov in the north and with a large complex of floodplain forest in the Zástudánčí National Nature Reserve in the south. This floodplain forest stretches along the Morava River further to the south to the town of Chropyně and forms the Special Area of Conservation Morava - Chropyňský Les in the frame of the Natura 2000 network (Machar et al.2007). The altitude of the study area ranges from 195 to $210 \mathrm{~m}$ a.s.l., the locality belongs to a warm climatic area (Quitt 1971) with the average annual temperature of 8,1$9.0{ }^{\circ} \mathrm{C}$ and the annual precipitation of $501-600 \mathrm{~mm}$. The bedrock is formed by unconsolidated floodplain sediments of clay, sand and gravel; in terms of pedology the fluvisols prevail (Culek 1996). Gravel mining is still intensive and its termination is planned for around 2040.

Apart from the ongoing gravel mining, the Tovačov Lakes are used for recreational swimming and sport fishing. In the centre of the area, there is an industrial factory producing concrete panels and a technological base of the gravel mining company. An allotment site lines the west margin of the lakes.

\section{Fig. 1: Localization of the area of study of the Tovačov Lakes:}

South margin of the town of Tovačov is in the left upper corner of the picture, the floodplain forest near the Morava River (Zástudánčí NNR) is in the right bottom quarter of the picture

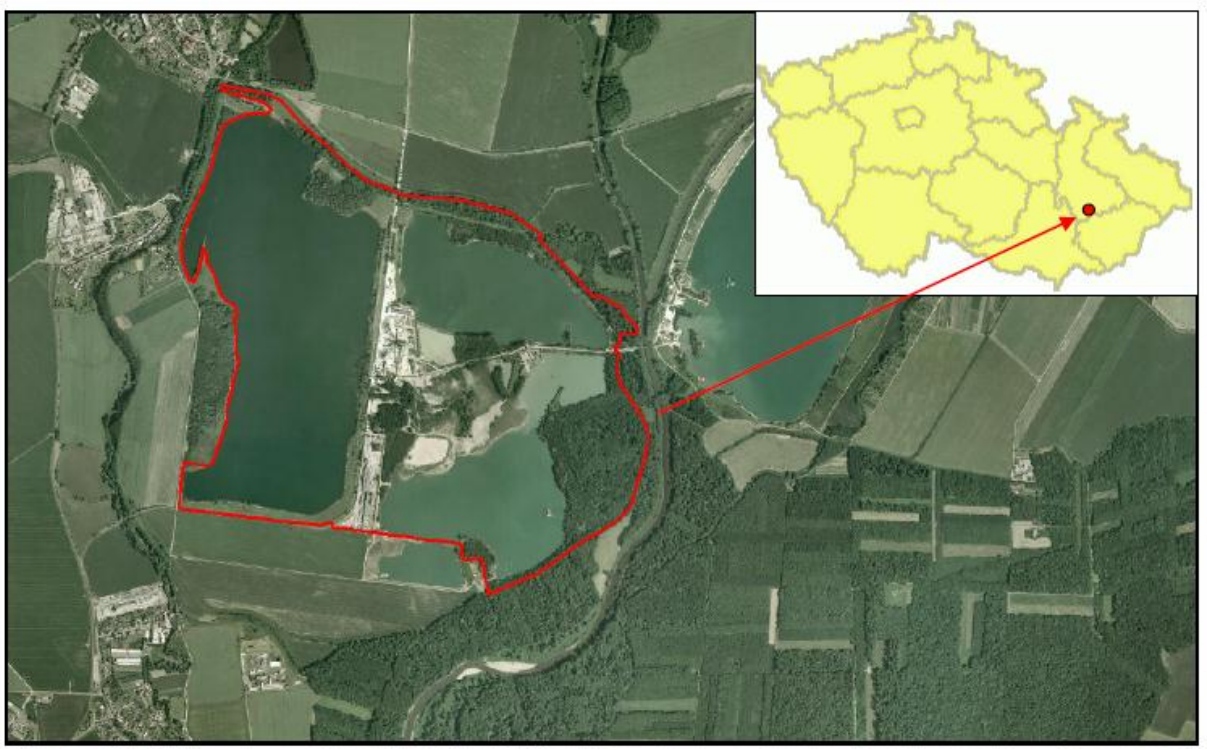




\section{Conflict of interests in the area}

A significant conflict of interests between the nature conservation and gravel mining arose in 2004 when the Agency for Nature Conservation and Landscape Protection of the Czech Republic integrated the large area of the Tovačov Lakes into the Natura 2000 network, namely into the proposed Site of Community Importance Morava - Chropyňský luh (locality code CZ 0714085, www.natura2000.cz). The reason was the occurrence of European beavers (Castor fiber) in a part of the Tovačov Lakes. It understandably provoked opposition of the mining company that had been using the whole area in compliance with the applicable legal regulations as a gravel mining area. The mining company asked the Palacký University in Olomouc for an expert study focusing on this problem. This expert study was compiled in three phases: phase 1 as historical study (Servus, Zifčák 2007), phase 2 as a landscape-ecological study of the area (Machar et al.2007), and the consequent phase 3 as a management plan proposal for the entire area (Servus et al.2008).

\section{Methodology of the historical and landscape analysis and a concept of solution of the conflict of interests in the area of study}

A study of historical development of the landscape was performed and used as an input for the landscape-ecological analysis of the area, because the role of mankind as the key species has been crucial in this significantly human-impacted landscape (Vitousek et al. 1997). The reconstruction of historical development of land cover was performed using 10 historical maps obtained in digital form with the help of Zoomify application from http://oldmaps.geolab.cz (Tab. 1), and surveying aerial photographs taken in 1938 - 1995 that were purchased from the Military Geography and Hydrometeorology Office (Tab. 2). The present state of the landscape was assessed using orthophotomaps from 2002.

Table 1: Summary of historical maps used for the landscape-ecological analysis in the area of study

\begin{tabular}{|c|c|c|c|}
\hline Type of map & Format & Scale & Time period \\
\hline Military mapping I & map scan & $1: 28880$ & $1779-1781$ \\
\hline Military mapping II & map scan & $1: 28880$ & $1836-1837$ \\
\hline Military mapping III & map scan & $1: 25000$ & 1876 \\
\hline
\end{tabular}

Table 2: Summary of surveying aerial maps used for the landscape-ecological analysis in the area of study (SAP - surveying aerial photograph; BPP - bit per pixel)

\begin{tabular}{|c|c|c|c|c|}
\hline Type of photograph & Format & Scale & Year & Color depth \\
\hline SAP & Contact copy & $1: 19600$ & 1938 & degrees of grey (8 BPP) \\
\hline SAP & Contact copy & $1: 21400$ & 1950 & degrees of grey (8 BPP) \\
\hline SAP & Contact copy & $1: 19000$ & 1962 & degrees of grey (8 BPP) \\
\hline SAP & Contact copy & $1: 39300$ & 1971 & degrees of grey (8 BPP) \\
\hline SAP & Contact copy & $1: 30000$ & 1981 & degrees of grey (8 BPP) \\
\hline SAP & Contact copy & $1: 21700$ & 1995 & degrees of grey (8 BPP) \\
\hline BPP & Digital raster & $1: 5000$ & 2002 & fully colored (24 BPP) \\
\hline
\end{tabular}


Maps were adjusted for the analysis by georeference (Lillesand, Kieffer 1995).

Grid maps were transformed into the system of geographic coordinates S-JTSK using photogrammetric points, the orthophotomap from 2002 was used as a reference grid). Grids of historical maps and surveying aerial photographs (SAPs) taken in 1938-1962 were transformed using linear polynomial, SAPs taken in 1971 and 1981 using polynomial of degree 2, and SAPs from 1995 using polynomial of degree 3 (Tab. 3). Surveying aerial photographs were also scanned.

Objects were classified into individual groups according to the system of land cover categories CLC 2000 - CORINE Land Cover 2000, which assess the degree of anthropogenic alteration on a scale of five degrees (Kolár 1996). This scale was interpreted in terms of degrees of ecological stability of the area according to the degree of anthropogenic alteration according to Löw \& Míchal (2003) - see Tab. 4.

After the analysis of historical development of the area, a comprehensive field examination was performed. It was focused on the revision and completion of habitat mapping according to the methodology of Guth (2002) and the inventory of selected animal taxa (invertebrates, fish, birds, population of European beavers).

Table 3: Parametres of georeferencing of grids for landscape-ecological analysis in the area of study (SAP - surveying aerial photograph)

\begin{tabular}{|c|c|c|c|}
\hline $\begin{array}{c}\text { Type of maps or } \\
\text { photographs }\end{array}$ & $\begin{array}{c}\text { Number of } \\
\text { photogrammetric } \\
\text { points }\end{array}$ & $\begin{array}{c}\text { Degree of } \\
\text { polynomial }\end{array}$ & Resolution (m/px) \\
\hline Military mapping I & 6 & 1 & 5,13 \\
\hline Military mapping II & 2 & 1 & 5,14 \\
\hline Military mapping III & 2 & 1 & 4,39 \\
\hline SAP 1938 & 3 & 1 & 0,41 \\
\hline SAP 1950 & 5 & 1 & 0,45 \\
\hline SAP 1962 & 3 & 1 & 0,40 \\
\hline SAP 1971 & 7 & 2 & 0,87 \\
\hline SAP 1981 & 9 & 2 & 0,70 \\
\hline SAP 1995 & 13 & 3 & 0,58 \\
\hline Orthophotomaps & 0 & 0 & 0,50 \\
\hline
\end{tabular}

Based on this data, a management plan was proposed for the entire area in compliance with the methodology commonly used for small specially protected areas in the Czech Republic (Anonymus 1999). Subsequently, the initiation and exploitation plan of gravel mining and the recultivation plan for the area were adjusted. It was necessary to choose a category of small specially protected area for the study area in compliance with the applicable environmental law (Miko et al. 2005). The category of natural monument was chosen after consideration, which can incorporate fragments of ecosystems or only a habitat of certain biological taxon (Míchal \& Petrríček 1998). In the adjusted recultivation plan, the maximum emphasis was given to the possibility of putting a natural habitat succession into effect. These purposes were reflected in the prediction of expected state of the area in 2040 (i.e. the state of the area at the planned gravel mining termination) 
Table 4: Comparison of degrees of ecological stability (DES) and CORINE Land Cover categories in the studied area

\begin{tabular}{|c|c|}
\hline Presumptive DES & CLC category in study area \\
\hline 0,5 & $\begin{array}{l}\text { 1 Artificial surfaces I } \\
121 \text { Industrial or commercial units } \\
122 \text { Road and rail networks and associated land } \\
\text { 131 Mineral extraction sites }\end{array}$ \\
\hline 1,5 & $\begin{array}{l}2 \text { Arable land I } \\
\qquad 211 \text { Non-irrigated arable land }\end{array}$ \\
\hline 2,5 & $\begin{array}{l}2 \text { Arable land II } \\
\qquad 231 \text { Pastures }\end{array}$ \\
\hline 3,0 & $\begin{array}{l}3 \text { Forests I (coniferous) } \\
312 \text { Coniferous forests } \\
324 \text { Transitional woodland-shrub }\end{array}$ \\
\hline 3,5 & $\begin{array}{l}2 \text { Arable land II } \\
242 \text { Complex cultivation patterns } \\
243 \text { Land principally occupied by agriculture, with areas of } \\
\text { natural vegetation }\end{array}$ \\
\hline 4,0 & - \\
\hline 4,5 & $\begin{array}{l}3 \text { Forests II (semi natural) } \\
313 \text { Mixed forests } \\
5 \text { Water bodies } \\
512 \text { Artificial water bodies }\end{array}$ \\
\hline 5,0 & $\begin{array}{l}5 \text { (Semi) natural forests, natural grasslands and wetlands } \\
311 \text { Broad-leaved forests } \\
411 \text { Inland wetlands } \\
511 \text { Water courses }\end{array}$ \\
\hline
\end{tabular}

\section{RESULTS}

\section{Historical development of the area of study}

The development of land cover in the area of study in the period from the late $18^{\text {th }}$ century till the early $21^{\text {st }}$ century see in detail in Fig.2. - Fig. 11.

LEGEND FOR FIGURES 2. -12 .

\begin{tabular}{|c|c|c|c|c|}
\hline TTT T T & & $\begin{array}{l}\text { Proposed natural monument } \\
\text { boundary }\end{array}$ & 242 & $\begin{array}{c}\text { Interim zone (between } \\
\text { shrubs and forests) }\end{array}$ \\
\hline \multirow[b]{2}{*}{ TTT T T } & & & 243 & Agriculture land \\
\hline & & $\begin{array}{l}\text { Proposed burter zone of } \\
\text { natural monument boundary }\end{array}$ & 311 & Deciduous forests \\
\hline & \multirow{2}{*}{121} & \multirow{2}{*}{ Industrial estate } & 312 & Coniferous forests \\
\hline & & & 313 & Mixed forests \\
\hline & 122 & Roads & 324 & Bushes and shrubs \\
\hline & 131 & Gravel mininig & 411 & Wetlands \\
\hline & 211 & Arable land & 511 & Water streams \\
\hline & 231 & Meadows & 512 & Water area (lakes) \\
\hline
\end{tabular}


The oldest map of the area of the Tovačov Lakes dates back to 1779-1781 (Fig.2.). Skašovský pond (Kaschow Teich) was a part of the pond system of the town of Tovačov (Topitschau). It covered the majority of the studied area at the beginning of the second half of the 18th century. There are distinct dykes stabilized by trees around the pond. A road can be seen in the crest of the dyke. Surrounding land was used as a broad-leaved forest and agricultural land - arable land and pastures. An open forest by the west border of the pond is a curiosity. It was possibly a grazing or otherwise intensively used forest. A floodplain forest covered the east part of the area.

Skašovský pond was abolished within the scope of a general trend of abolishment of ponds and their conversion into arable land that was connected with the introduction of sugar beet to the Haná region during the 1780s and 1790s. The pond is no longer shown in the maps of the studied area from 1836 (Fig.3.) from the second military mapping.

The dominance of agricultural land is still recognizable in the area of study in 1876 (Fig.4.) although it does not cover as large area as in the 1830s. On the other hand, the proportion of waterlogged land increased, which was supplied by the underground water from the Morava River and its branches. A new forest formed near the east border of the area, which preserved until the present day. Due to the character of the maps it is not possible to determine the type of the forest, but considering the altitude and the proximity of a water course, it can be assumed that it was a floodplain forest.

A typical mosaic of agriculture land in the early of the $20^{\text {th }}$ century is on the aerial photo of the studied area on Fig.5. More agricultural land, which occupied about $90 \%$ of the area, was created by draining the formerly waterlogged localities. One half was formed by blocks of fields of arable land, the other half by a mosaic of small temporary permanent cultivation areas with gaps of uncultivated and barren land. A floodplain forest can be seen in the south-east part of the area; it is probably a result of logging. Trees with preservation order and younger subdominant trees are left here as a base for a future tree layer. It probably used to be a standard-with-coppice forest.

An initial sign of gravel mining appeared by the north border of the study area in 1950 (Fig.6.). High underground water level in the floodplain flooded the excavations and water bodies formed. Their area was about 1.3 ha in 1950 (fifty years later it was 212 ha, see Fig.11.). Land use of the adjacent areas remained unchanged, still with a large proportion of the mosaic of small temporary and permanent cultivation areas. A floodplain forest had been continuously spreading around the Skašovský dyke that forms the north and a part of the east border of the reserve.

The mosaic character of fields did not remain after 1962 (Fig.7.), the last remnants can be found outside of the study area, southeast of its border. The level of ecological stability is the lowest within the studied 250 years (Fig.13). Gravel mining was performed from water level using floating dredgers. As a consequence of the continuous gravel mining, the surface area of water bodies enlarged into 41 times the original one in the period from 1950 to 1962 when it was 54 ha. Also the area of the mining place service infrastructure increased. The result of the land consolidation was an almost entire disappearance of small fields that were replaced by larger blocks of arable land. Management interventions are also apparent in the forests in the southeast part of the area. 
Fig. 2: Land cover analysis of the area of the Tovačov Lakes in 1779
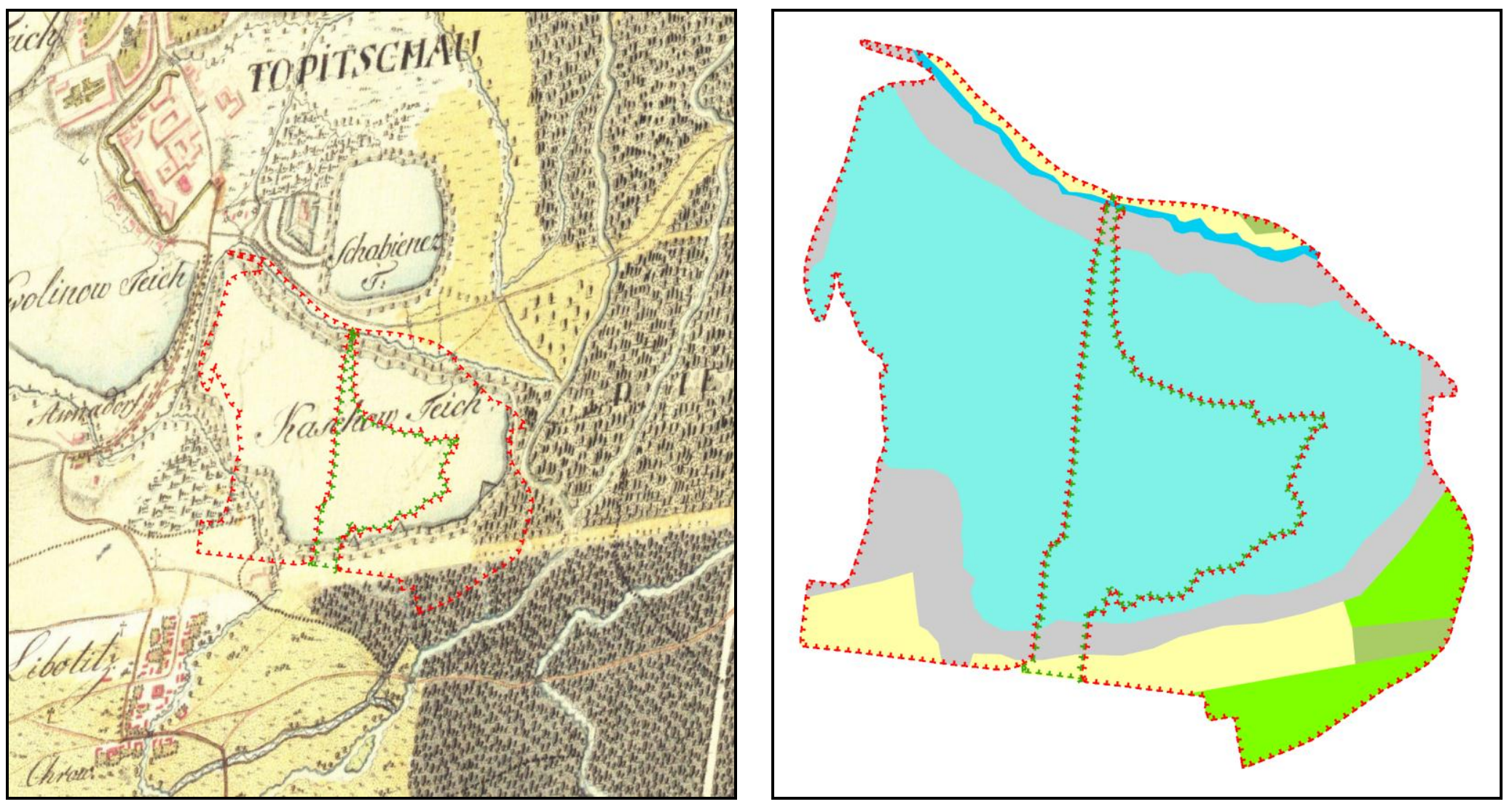
Fig. 3: Land cover analysis of the area of the Tovačov Lakes in 1836

Boundaries of the proposed Natural Monument Tovačov Lakes delineated on an underlying map from Military mapping II
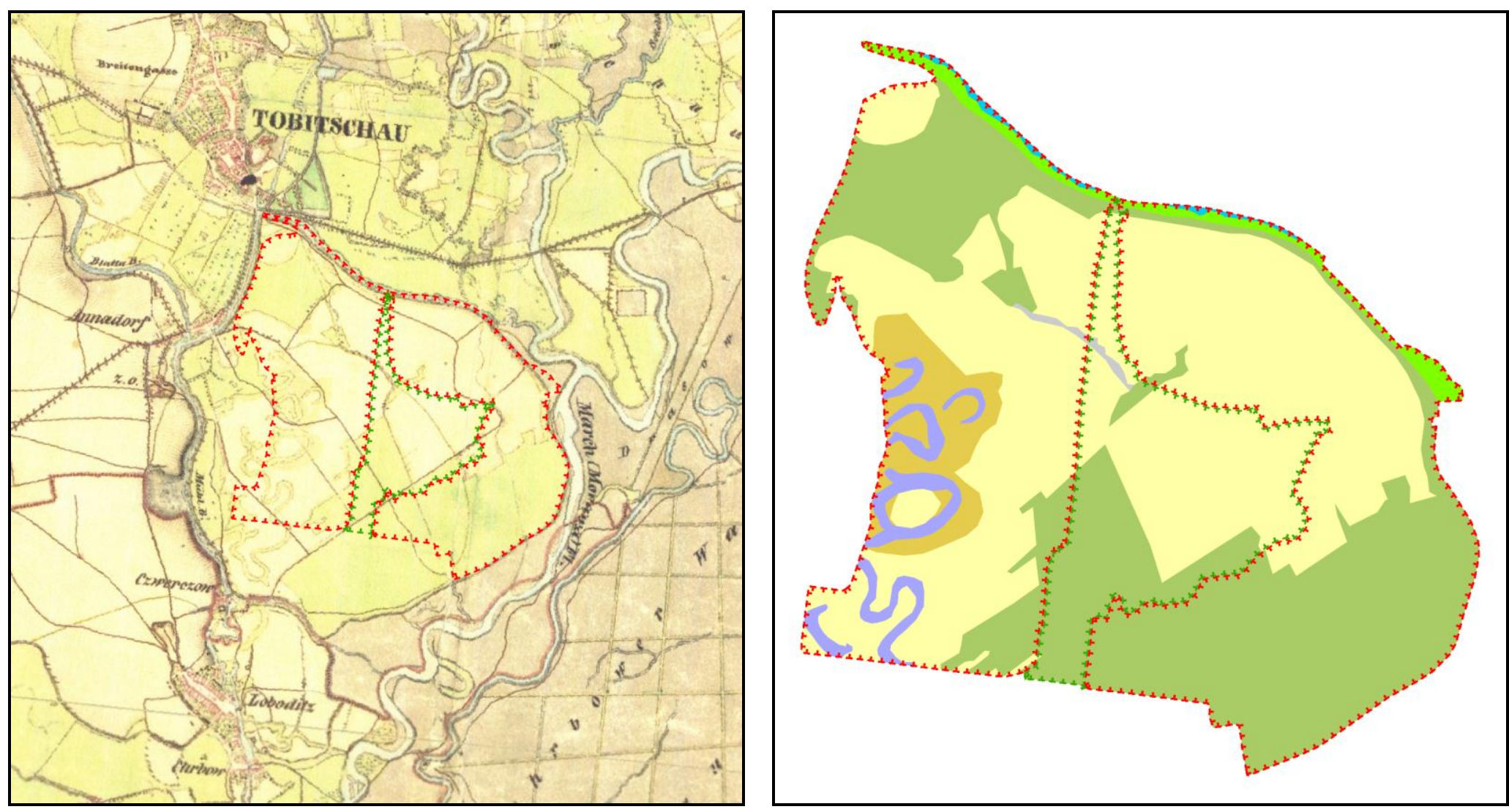
Fig. 4: Land cover analysis of the area of the Tovačov Lakes in 1876 - map from Military mapping III
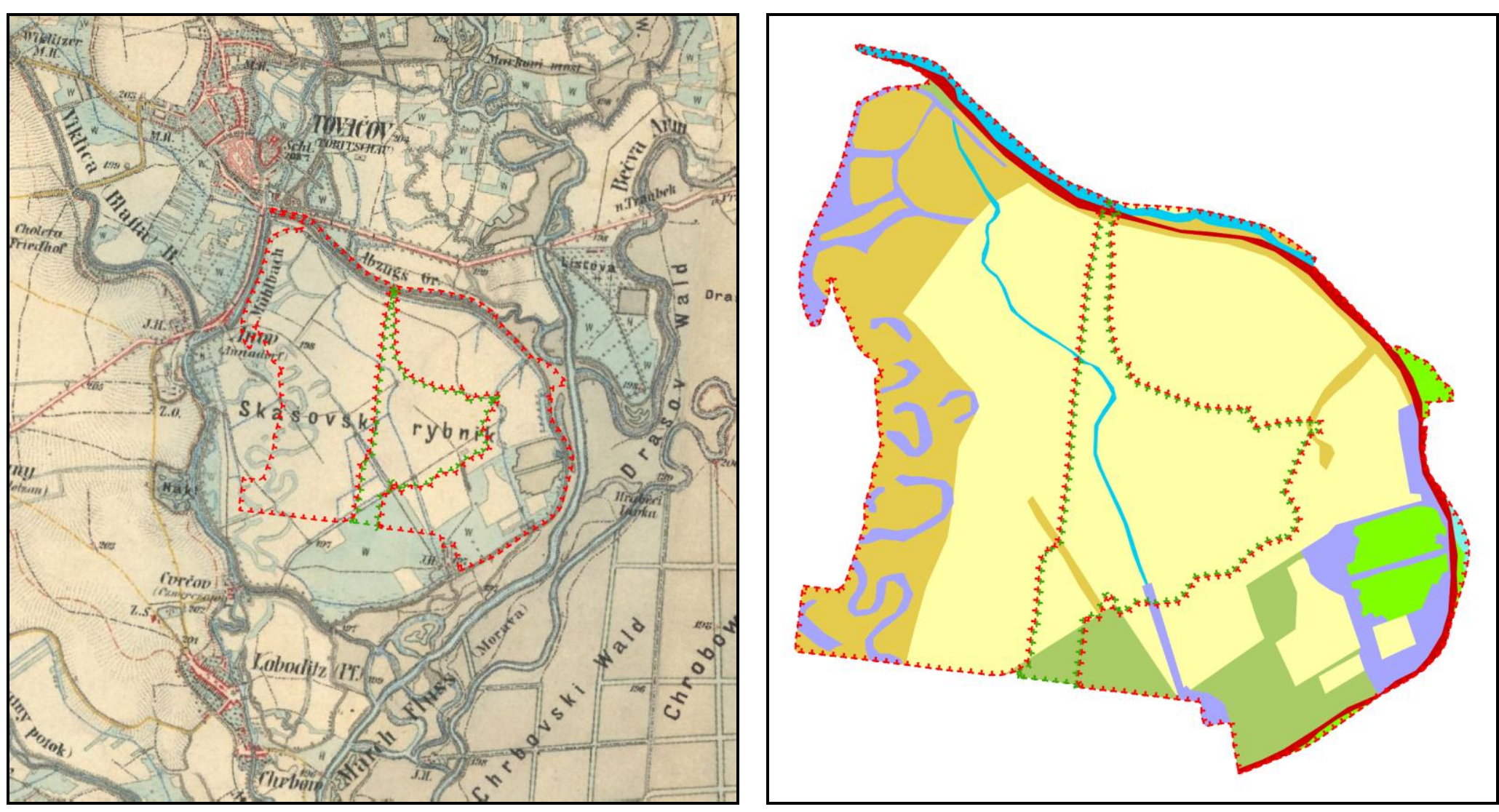
Fig. 5: Land cover analysis of the area of theTovačov Lakes in 1938

Boundaries of the proposed Natural Monument the Tovačov Lakes marked on an underlying aerial photograph taken in 1938.
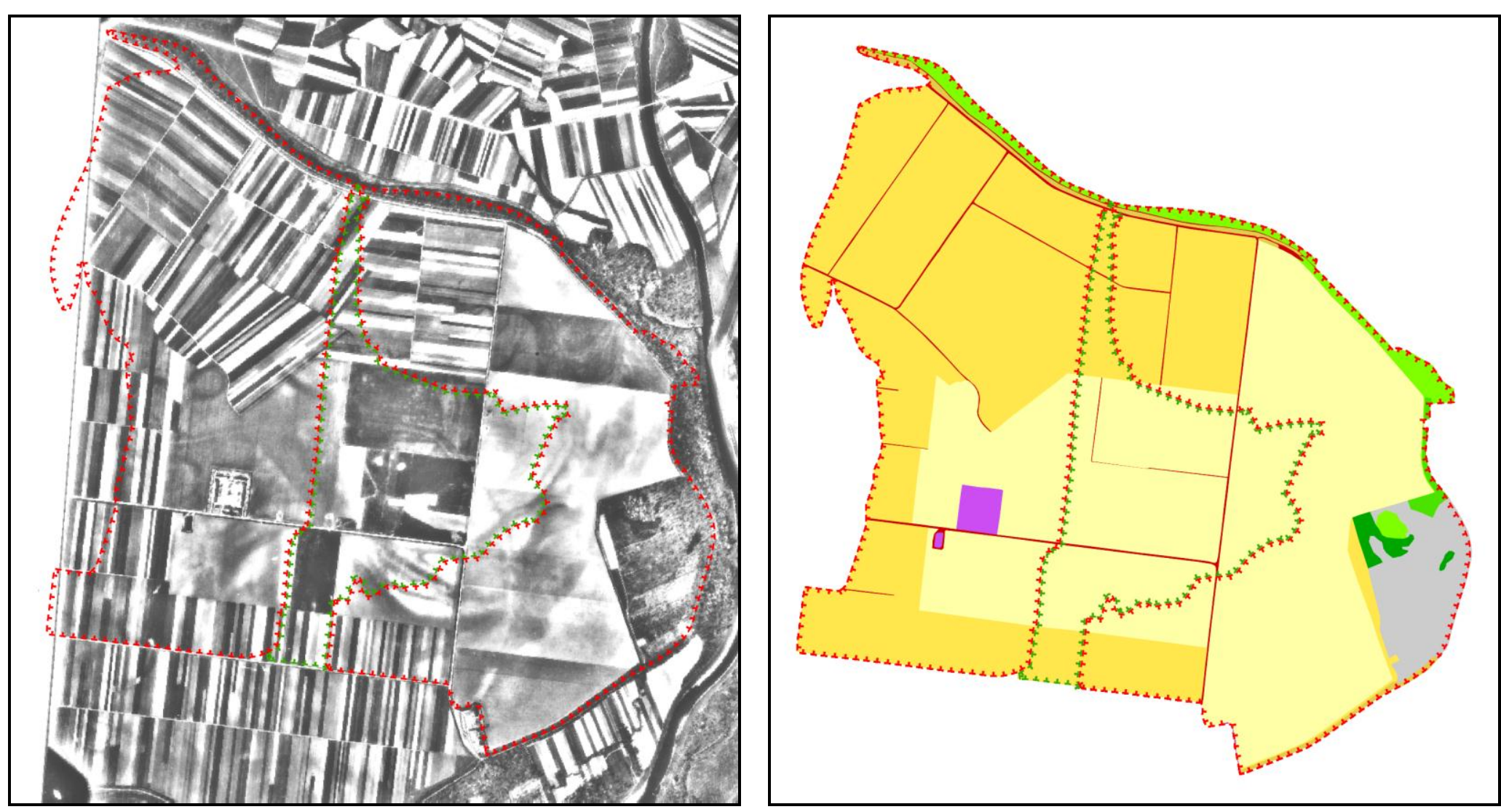
Fig. 6: Land cover analysis of the area of the Tovačov Lakes in 1950
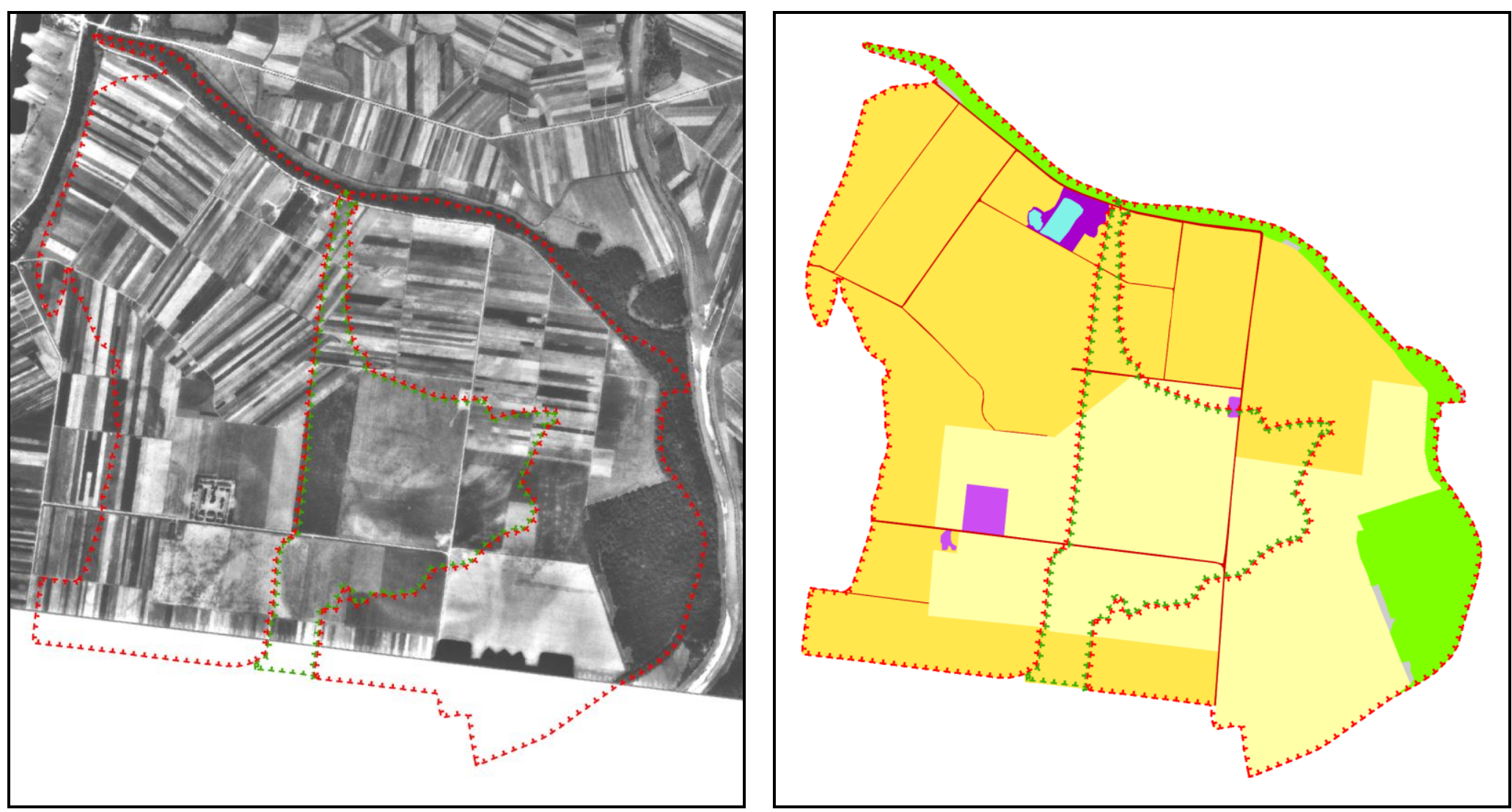
Fig. 7: Land cover analysis of the area of the Tovačov Lakes in 1962
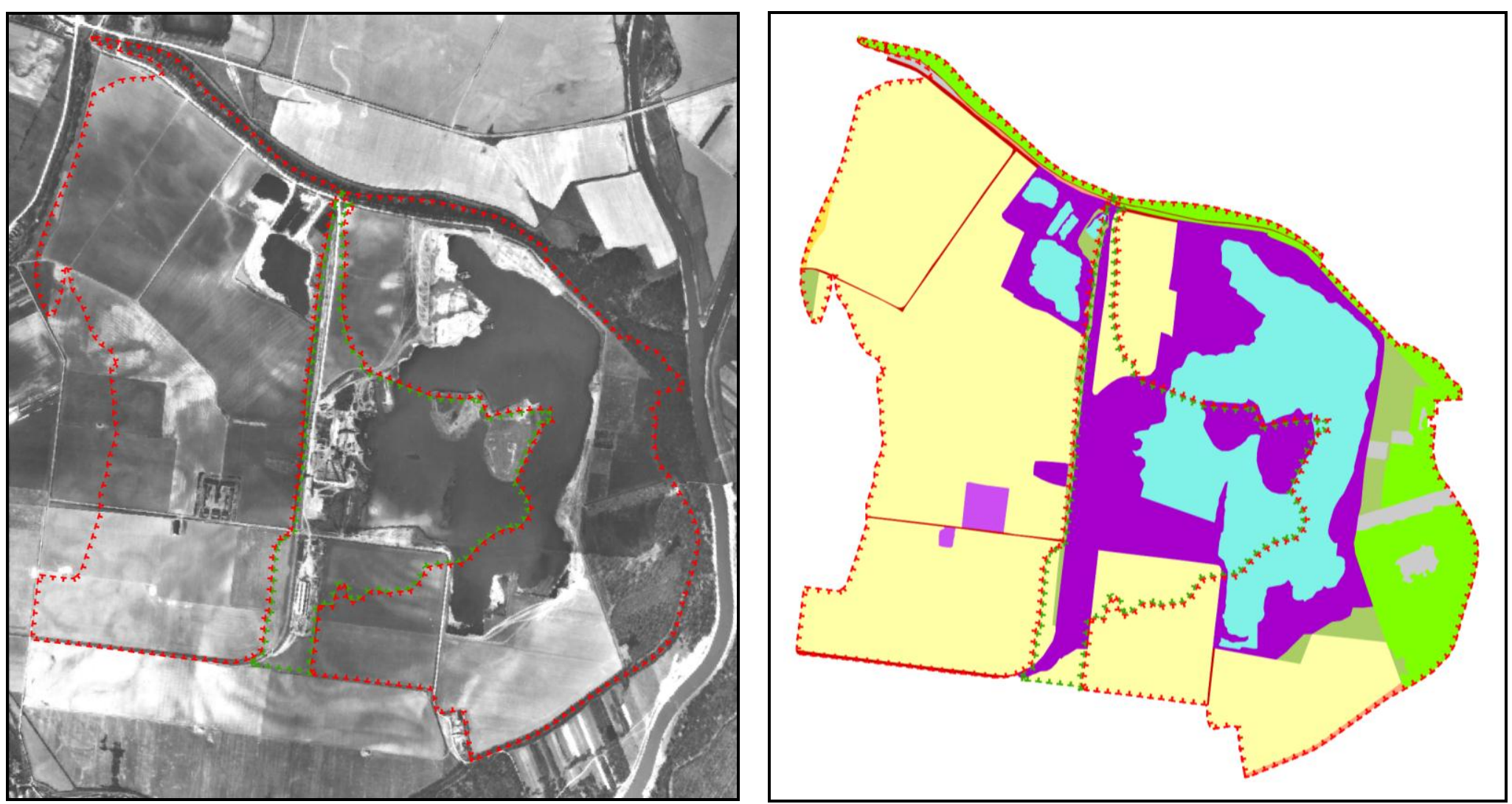
The general character of the agriculture remains unchanged. Large blocks of arable land formed the basic character of the landscape in 1971 (Fig.8.). The overall ecological stability of the landscape is low (Fig.13.). The size of the surface of water bodies continuously grows and the character of the area changes. Borders of forests and lakes began to evolve and the shorelines of the eastern lakes had gradually stabilized. The surface area of Anínské Lake progressively grows. The surface area of the lakes in east is stabilized. The area of the mining place service infrastructure is definitively set too. A total water surface area amounts to 138 ha, which represents $70 \%$ of the present situation.

The last small fields disappeared from the landscape in the study area in 1981 (Fig.9.). Widening of water bodies in the area reached its maximum. The shorelines of Anínské Lake are stabilized too. Unsuitable pine and spruce forests were planted at open places around the lakes in this time period. Pioneer tree species (aspen, birch) established themselves in a part of the area, oak trees and ashes spread locally from the adjacent floodplain forest.

The area of all lakes was stabilized and reached its maximum of 211 ha in 1995 (Fig. 10.). The area of mining infrastructure amounted to 31 ha. Arable land completely disappeared from the area. The area of forests slightly grew but they were mostly nonnative pine and spruce plantations. Cleared strips or newly forested areas remained after logging in the southeast part of the area of study.

No marked changes of the landscape character occured in 2002 (Fig. 11.). The depth of the lakes was changing locally due to mining or clay sludge discharge. The size and location of other landscape units was basically identical with the present situation in 1995 . A positive feature was the expansion of tree vegetation to the barren localities at places that are not affected by the displacement of material connected with gravel mining. The area of the present gravel lakes is about 200 ha. Together with locally developing littoral areas, riparian vegetation and floodplain forest, the lakes form secondary natural habitats, which are generally missing in the intensively used, mainly agricultural landscape.

The analyzed maps show that the floodplain in the area of the Tovačov Lakes was continuously used as arable land from the end of the $18^{\text {th }}$ century till the 1960 s. Gravel mining was initiated then and led to the formation of water bodies and their gradual enlargement. The area of the lakes reached approximately 200 ha at the beginning of the 1990s (Fig.10.) and stayed in this extent until present day (Fig.11.). The results of the assessment of historical development of the Tovačov Lakes show that the locality of mining place in this type of landscape is beneficial in terms of ecological stability and certainly also in terms of biological diversity. An area of diverse benefits for the adjacent land stays in places of mined-out deposits instead of a "scar in the face of the landscape". The mining area paradoxically becomes one of the most valuable and most natural places in intensively used agricultural landscape. 
Fig. 8: Land cover analysis of the area of the Tovačov Lakes in 1971
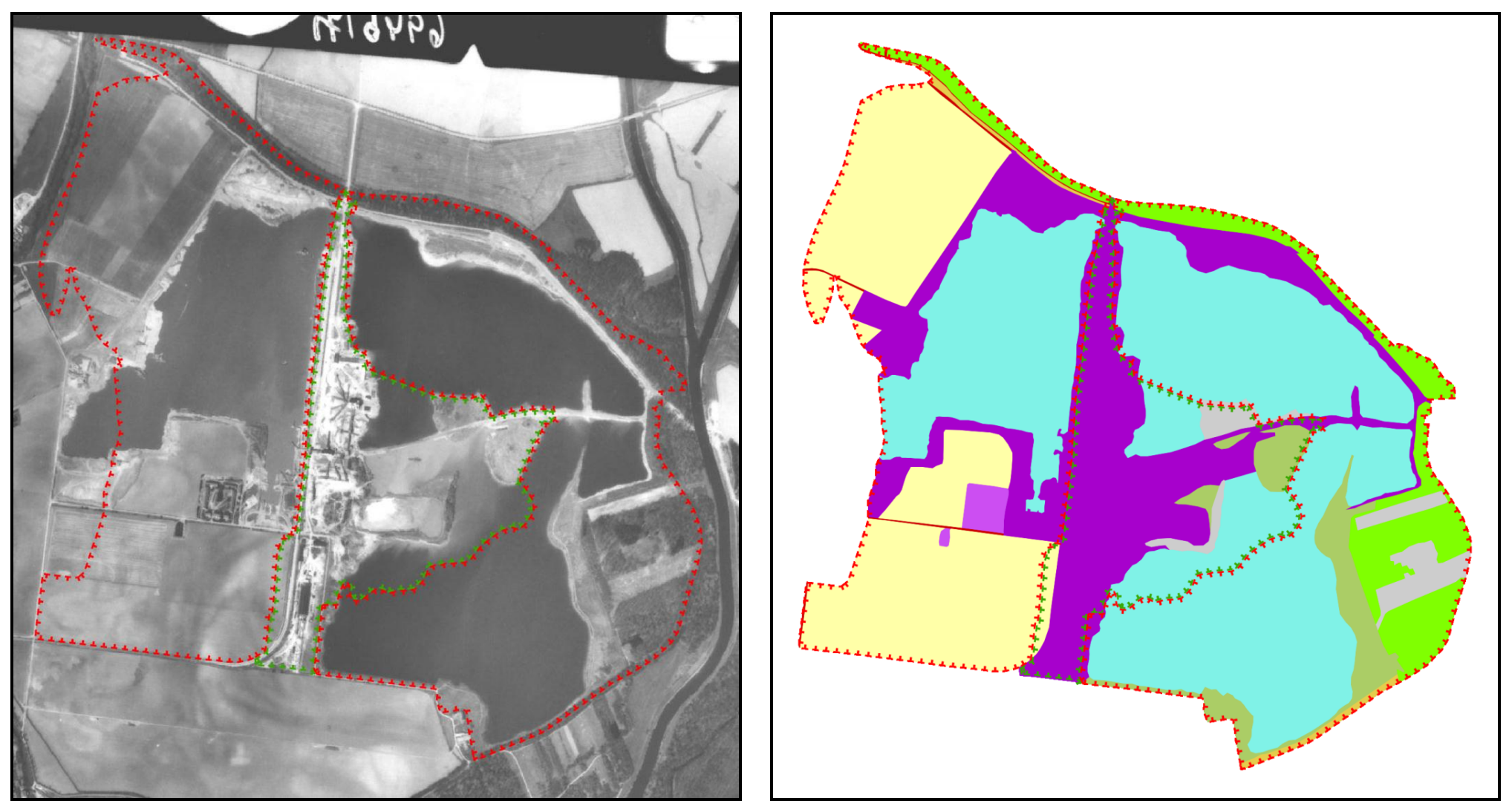
Fig. 9: Land cover analysis of the area of the Tovačov Lakes in 1981
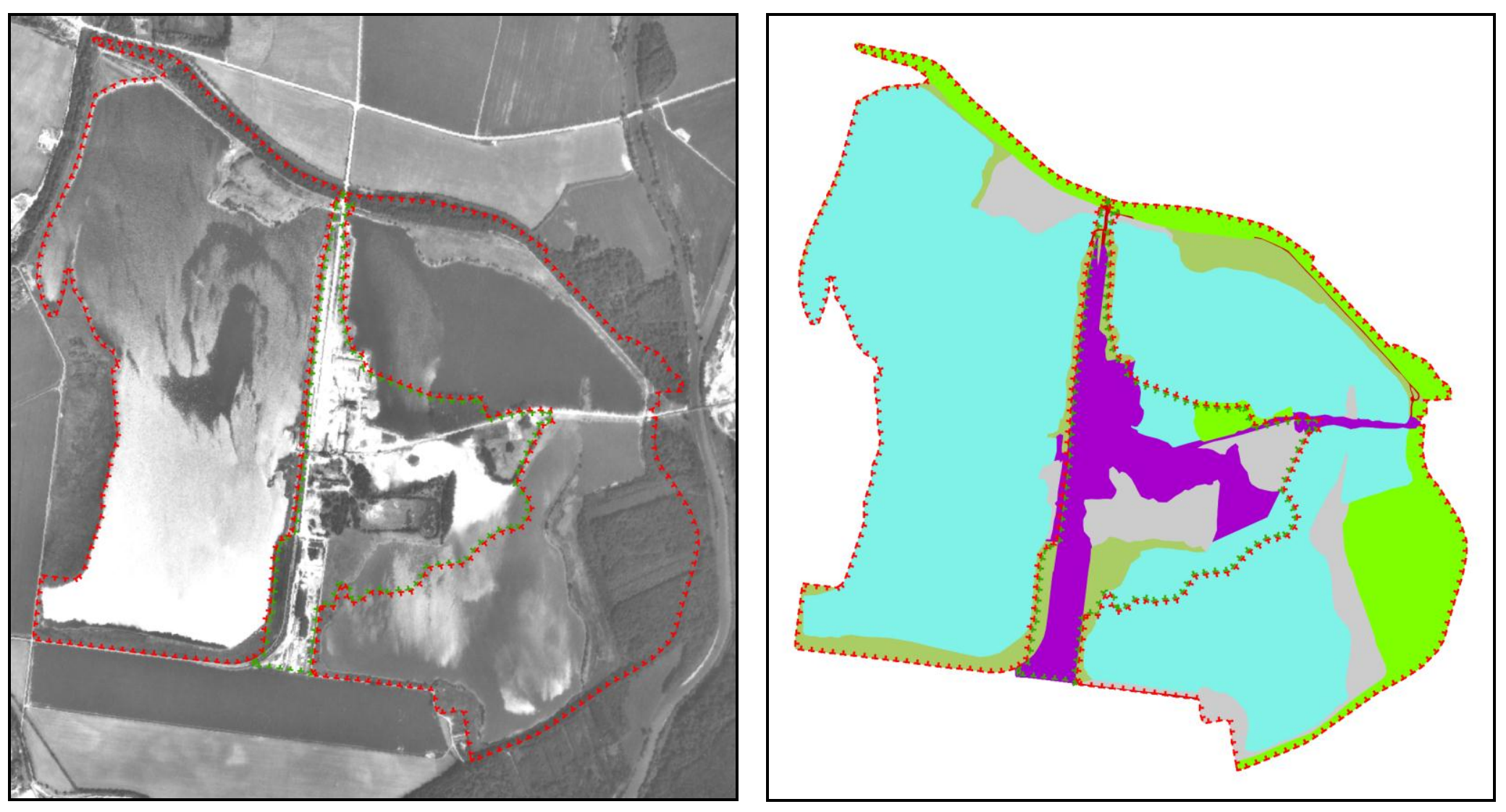
Fig. 10: Land cover analysis of the area of the Tovačov Lakes in 1995
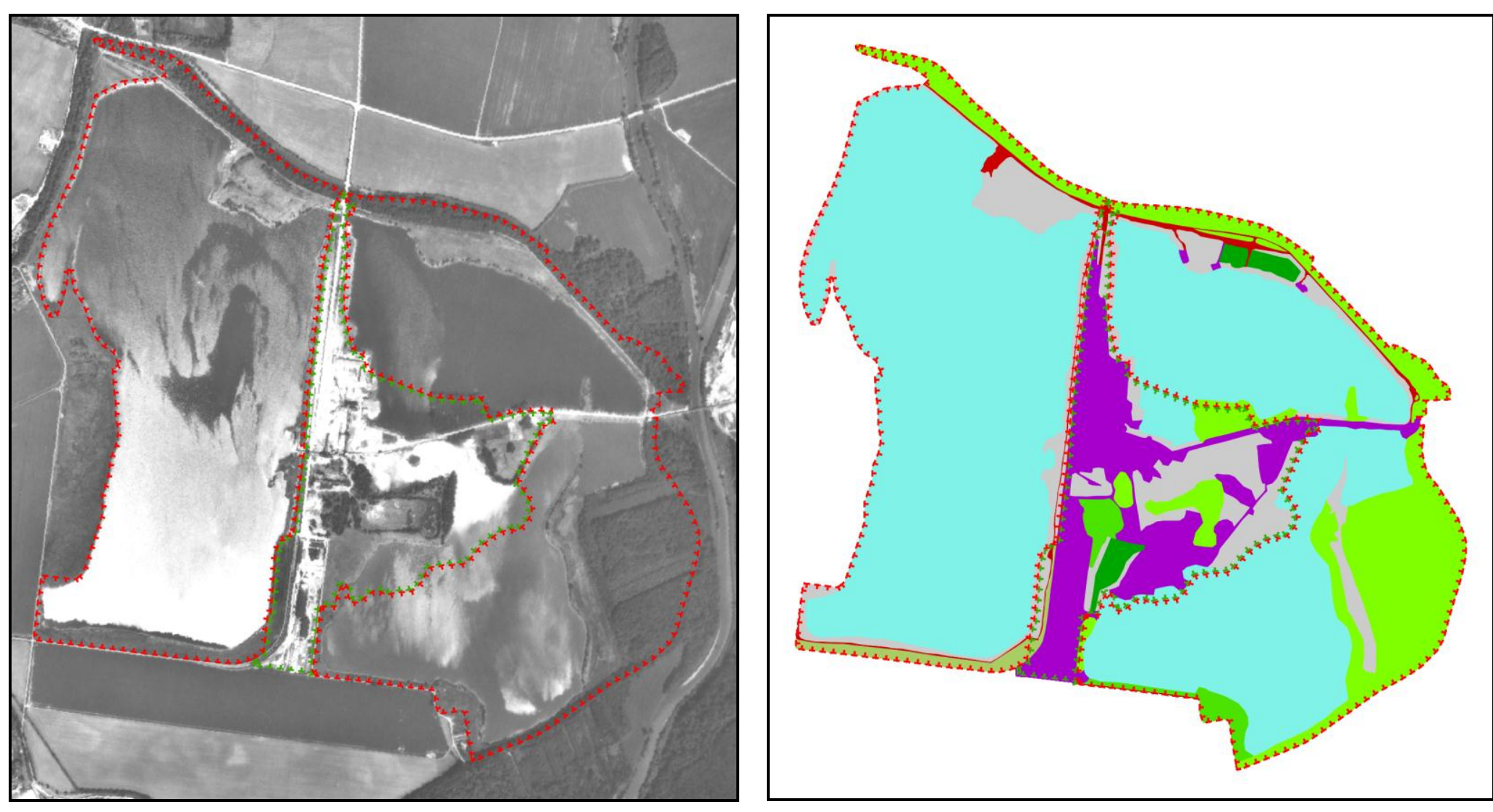
Fig. 11: Land cover analysis of the area of the Tovačov Lakes in 2002
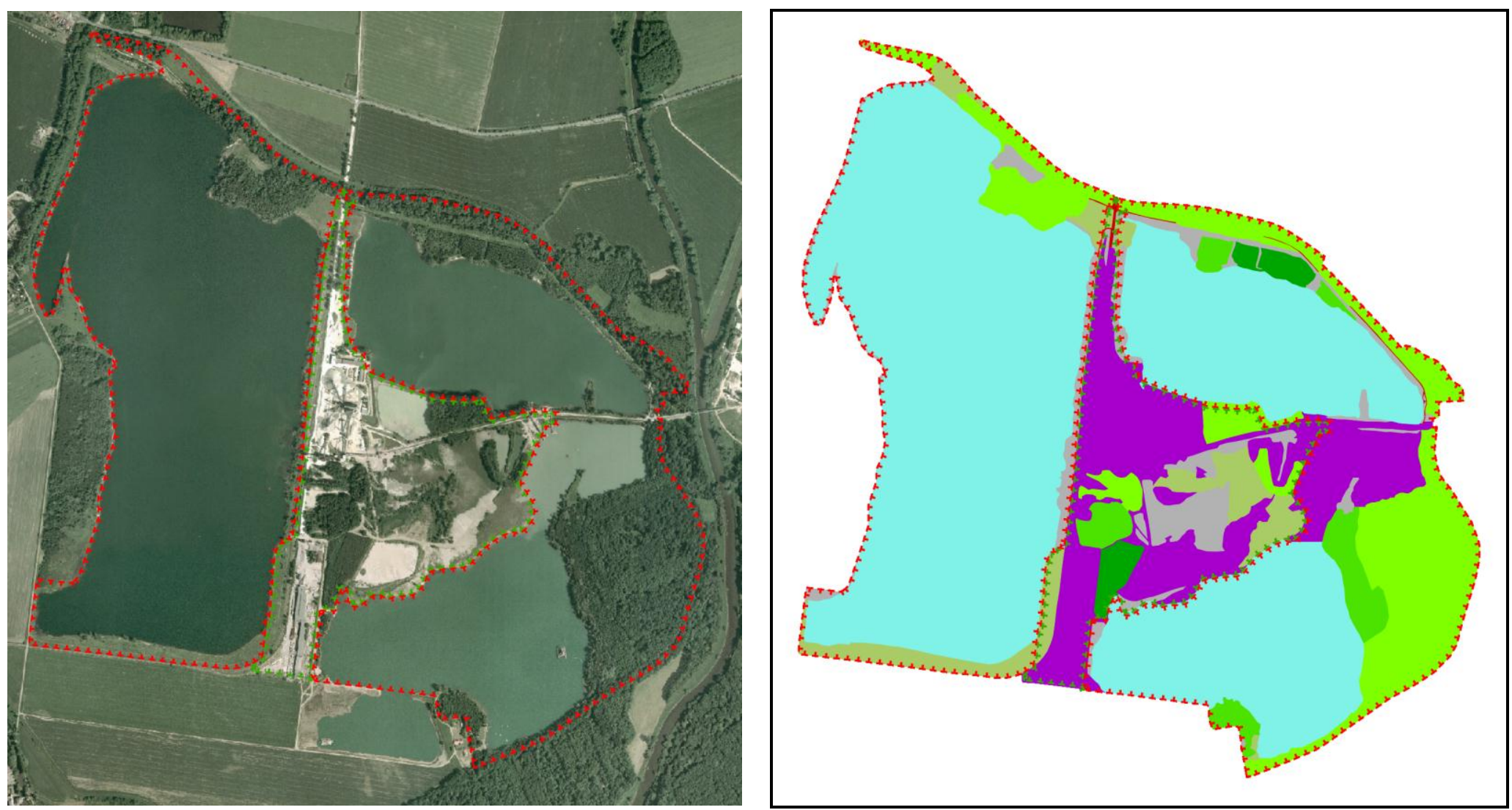


\section{Historical changes of land use and ecological stability of the area of study}

Fig.12. show an overview of changes in land use categories in the area of the Tovačov Lakes over the time period from 1779 with a prediction up to 2040, which reflects proposals of the area management plan (Servus et al. 2008).

Fig. 12: Percentage proportions of land use categories (CLC 2000) in the studied area of the Tovačov Lakes in $1779-2040$

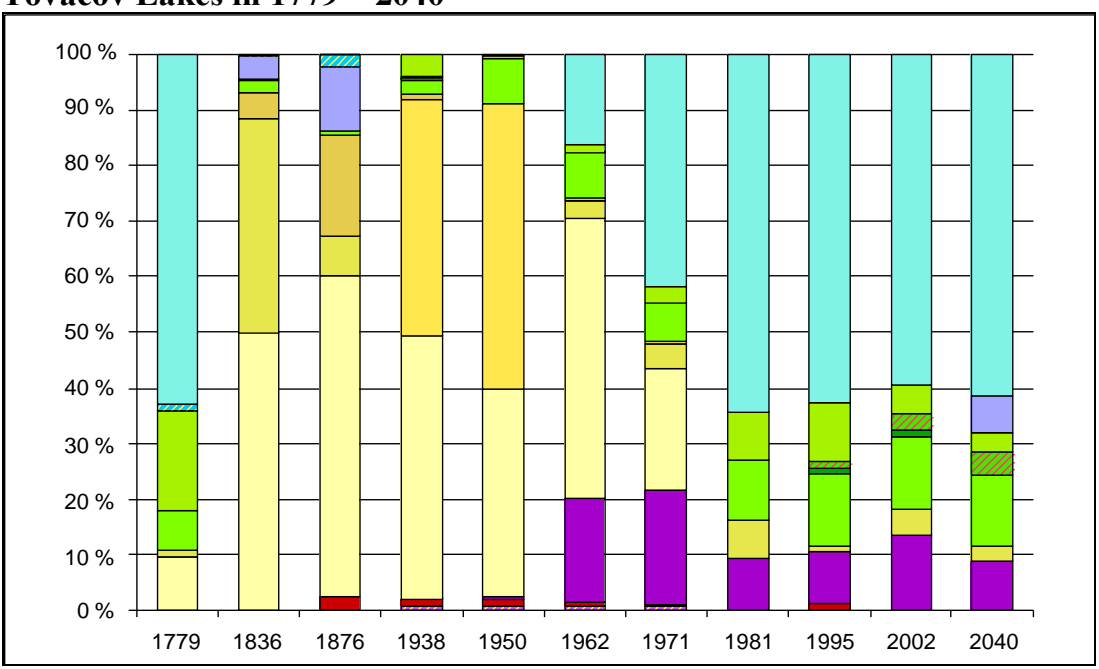

The development of the degree of ecological stability (DES) in the area of study (Fig.13.) reflects mainly the proportion of arable land and water surfaces. The analysis shows that the maximum values of DES (3.8-3.9) were obtained at the beginning of the analyzed historical period (Skašovský pond in the late $18^{\text {th }}$ century) and again at present day (lakes of gravel mining origin).

Fig.13: Changes in the degree of ecological stability in the area of the Tovačov Lakes from 1779 to prediction up to 2040

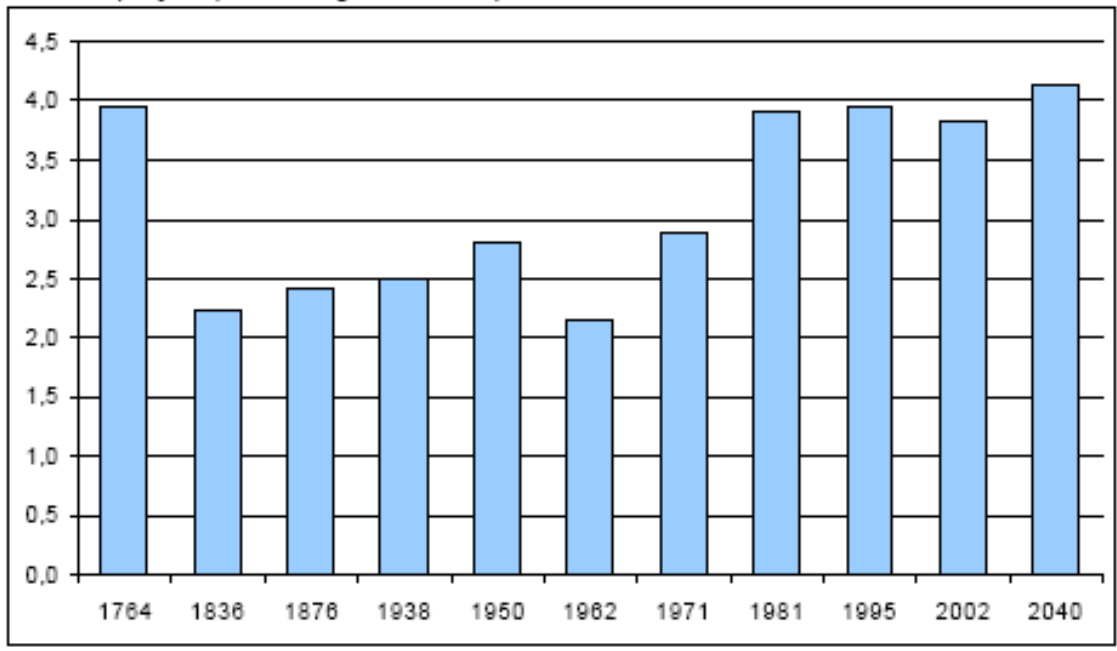




\section{Current biota of the area of study}

Habitat mapping showed that valuable habitats can be found in a heavily humanimpacted mining area. These are particularly littoral areas at shorelines and fragments of floodplain forest habitats that are mainly formed by self-originated fragments of softwood floodplain forest at lake shores (Tab.5.). An interesting part of the study area in terms of botany is the railway (rail siding) with the occurrence of interesting thermophilous species such as e.g. Filago arvensis, Amaranthus albus, Portulaca oleracea, Peplis portula, Festuca psammophyla (Tlusták in Machar et al. 2007).

\section{Table 5: Forest habitats in the studied area}

\begin{tabular}{|l|l|}
\hline Habitat & Relative share of study area (\%) \\
\hline $\begin{array}{l}\text { Hardwood floodplain forests of } \\
\text { lowland rivers }\end{array}$ & 6 \\
\hline $\begin{array}{l}\text { Natural seedings of pioneer tree } \\
\text { species }\end{array}$ & 4 \\
\hline Hornbeam forests & 2 \\
\hline Willow-poplar floodplain forests & 2 \\
\hline
\end{tabular}

Zoological surveys revealed 18 specially protected insect species (Bezděčka in Machar et al. 2007) and 32 fish species (Loyka in Machar et al. 2007) one of which was specially protected (Lota lota). 71 bird species occur in the area, eight of which are listed in the Annex I of the Council Directive 79/409/EEC on the conservation of wild birds (Bureš in Machar et al.2007). The population of European beavers (Castor fiber) in the area of the Tovačov Lakes comprises of one family of $6-12$ individuals. Their activity is restricted to certain parts of the area (Fig.14.). Survey results (Kostkan in Machar et al. 2007) indicate that the presence of mankind (gravel mining and fishermen in this case) has no impact over the beaver population.

\section{The prediction of further development of the studied area and management plan}

The management plan of the Tovačov Lakes involves a set of proposed measures for the regulation and control of gravel mining and a recultivation plan adjustment. The deposit area of the Tovačov region is divided into some deposit regions. Regions I, III and IV (numbers see Fig.14.) are located within the proposed specially protected area. Mining was terminated in the 1950s in Lake Tovačov I (the northeast lake) when the gravel was mined out to the depth of $8 \mathrm{~m}$. The remaining material below this level is mineable. The deposits in Lake Tovačov III (the west lake) have also been extracted. This lake is going to be used as a water-supply reservoir instead of Tovačov I. Lake Tovačov IV (the southeast lake) is a continuation of Lakes Tovačov I and II. The mining activity is planned throughout the period under consideration until 2040 in the following steps:

1. After the exploitation of DP Tovačov I (outside the study area), the mining activity will be focused on the area of DP Tovačov V. Here, mining will be performed to the maximum depth of $30 \mathrm{~m}$.

2. Mining down to the basis of DP Tovačov I with an expected maximum lake depth of $35 \mathrm{~m}$.

3. Mining in DP Tovačov III so that the depth of 10-15 $\mathrm{m}$ will be reached in the southern part, with a gradual slope towards the northern part where a depth of 30 $\mathrm{m}$ is expected.

4. Mining in the south and central part of DP Tovačov IV, with a maximum depth of $35 \mathrm{~m}$. 
Fig.14: Population of European beavers (Castor fiber) in the area of study the Tovačov

\section{Lakes}

Red point: Active beaver lodge

Green point: Browsing, slides and other signs of stay of beaver

Yellow point: Inactive burrows

Number of lakes: I: water-supply reservoir (Anínské Lake); III: Velké Lake; IV: Skašovské Lake

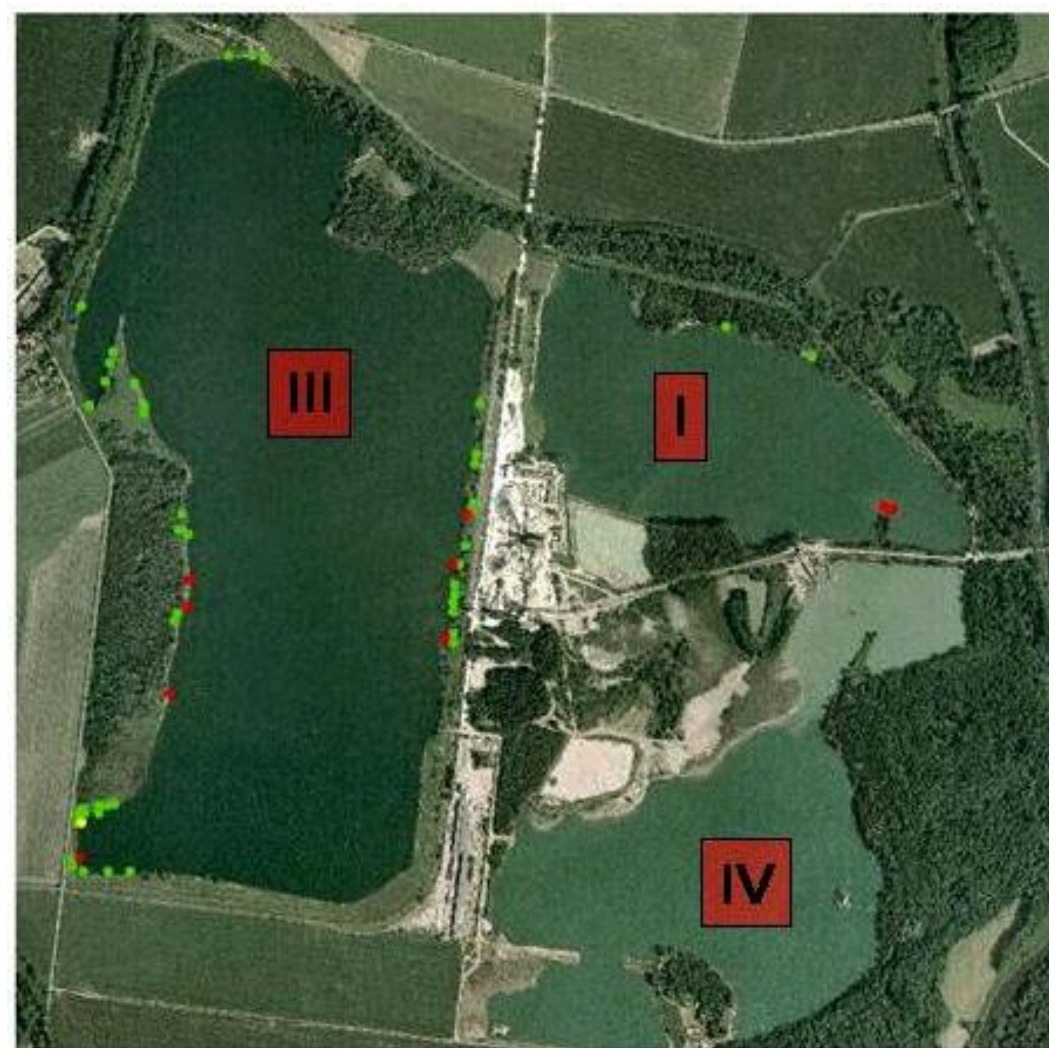

For the prediction of the habitats development, the Management Plan (Servus et al. 2008) takes into account especially the predicted lake depths. The gravel mining technology will be directed towards the creation of large littoral areas, higher diversification of lake shores and simultaneously towards the formation of sheer lake banks suitable for nesting of birds (kingfishers, sand martins). The management plan accepts also a possible recreational use of one of the lakes in the future and proposes the principles of fish management (oriented towards the creation of conditions suitable for wide spectrum of autochthonous fish species and their natural reproduction). The recultivation plan emphasizes natural succession at mined-out areas, which is immensely dynamic and fast in the conditions of floodplain areas (Buček et al. 2002). Fig.15. shows a predicted state of the area of theTovačov Lakes in 2040 under the condition that the management plan will be respected. 
Fig.15: Prediction of land cover in the area of the Tovačov Lakes in 2040:

Boundaries of the proposed Natural Monument the Tovačov Lakes (red) marked on an underlying aerial photograph (2002) with marked new littoral areas (yellow) in the predicted state in 2040
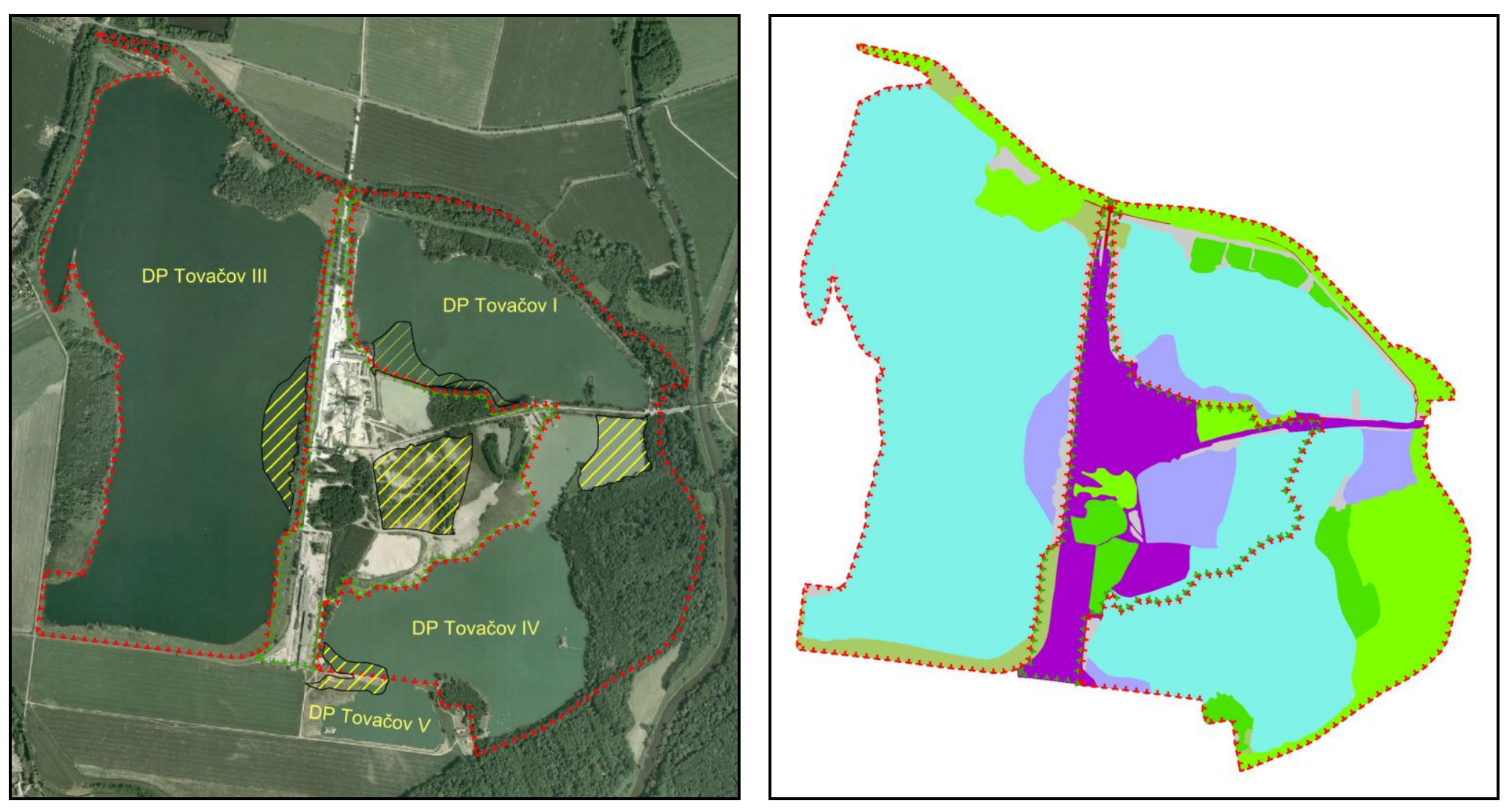


\section{Succession and restoration of floodplain forest geo-biocenoses}

The development of land cover in the area of the Tovačov Lakes is currently conditioned mainly by gravel mining and by processing of the extracted material. Fine bedrock particles are washed out during the gravel cleaning. These particles are deposited back to the mined-out places at deep parts of the lakes. The management plan proposes to deposit these fine particles at shore parts of the lakes, which would enable the creation of large shallow littoral areas, where also a natural succession of initial stages of floodplain forest can be expected. Due to the technological limitations of the deposition, these areas, which are designated for the future floodplain forest, are concentrated in the central part of the area near the mining infrastructure (Fig. 15.). The management plan expects the formation of about 12 ha of new littoral habitats (reed-swamps) and about 21 ha of new floodplain forest habitats. Considering the high underground water level that will presumably correlate with the lake's water level, the succession at these sites will probably lead to softwood floodplain forest habitat types and alder - willow stands (Fig.15.). Formation of larger littoral areas is expected especially in the central part instead of the current mining infrastructure. The formation of littoral areas will be regulated by the Management Plan. A gradual transformation (change of species composition) of the unsuitable pine and spruce plantings around the lakes towards mixed forests is expected with a prospect of complete elimination of spruce and pine in the area of study.

The management plan also proposes a change in species composition of the pine and spruce plantings around the lakeshores that are unsuitable for the site and that were already planted within the recultivation. These changes will be directed towards a tree species composition corresponding with hardwood floodplain forests (hornbeam-elm-ash forests) and will be realized at several localities with the total area of 14 ha.

\section{DISCUSSION AND CONCLUSIONS}

The presented case study from the area of the Tovačov Lakes suggests that understanding of historical aspects of its development can be important for management of a particular landscape (Křováková 2009). The methodology that was used in this study within georeferencing (Pechanec 2006) of historical maps and aerial photographs (Packalén et al. 2008) and subsequent classification of objects into individual groups according to the system of CORINE land use categories was used e.g. for the resolving of problems with revitalization of the landscape in the Vysoké Tatry Mountains after the catastrophic windthrow damage (Sládek \& Vokŕálová 2006).

The character of the maps from the first military mapping (Fig. 2.) reflects their military use (Boháč 1975). Objects and phenomena important for military needs were the priority in both graphical and written forms. The second military mapping of the area of Moravia and Silesia was performed in 1836-1840 after the military triangulation in 1806-1811. Therefore, in contrast to the first military mapping, a prerequisite for geodetic unification of the whole map product was created (Kuchař 1967). Existing maps were no longer sufficient for the army needs and the progressing industrial revolution (the construction of roads and railways, the development of towns and cities) and, therefore, the so called third military mapping was initiated in 1869. The area of Moravia and Silesia was mapped in 1836-1840 (Fig.4.). Cadastral maps were used as a basis, and the hypsography, in the form of hatches, contour lines and spot heights, was depicted in the new maps of the original scale of 1:25 000 (Lipský 2000). 
A relationship between history and restoration ecology in Europe is important especially in the frame of floodplain and river ecosystems (Petts et al. 1989) and it has an impact for biodiversity these ecosystems (Ward \& Tockner 2001). It was successfully used for example in the Danube Restoration Project (Schiemer et al.1999).

Also the relationship of landscape ecology and restoration ecology is close because the restoration of impaired ecosystems and ecosystem services can only be resolved in the context of the landscape (Prach 2009a). Moreover, the application of restoration ecology can practically verify a series of landscape-ecological concepts (succession theory, relationships of biodiversity and disturbances in the landscape, island biogeography theory, theory of species pool, metapopulation functioning, practical aspects of biological invasions etc. (Aronson \& Van Andel 2006; Walker et al. 2007).

Among the current topics of restoration ecology in the Czech Republic belong: restoration of cultural landscape ecological stability by the formation of ecological networks (Buček et al. 2007), restoration of ecosystems on arable land (Simon \& Buček et al. 2008), restoration of areas affected by mining (Cílek 1999), restoration of river ecosystems (Just et al. 2003; Vrána et al. 2004) and restoration of ecological stability and natural composition of forests (Míchal et al. 1992). In floodplain forests, specific issues of revitalization of water regime in the floodplain join in (Siebel 1998; Klimo et al. 2008).

The primary succession of floodplain forest communities in barren areas is very quick and dynamic, which was demonstrated e.g. in the study of revitalization of the middle Nové Mlýny reservoir (Buček et al. 2004). A limiting factor of a successful development of naturally formed initial stages of floodplain forest is the duration of flooding or elevated underground water level during the vegetation period and the composition of soil substrate. Stands formed by primary succession that are dominated by willows and poplars are adapted to flooding, but sixty or more days of summer flood are lethal for a majority of poplars (Maděra 2003).

There is an ongoing discussion in the literature about leaving the mined-out areas of former quarries to the natural succession and about their importance for nature conservation as refugia in cultural landscape (Chuman 2007) or for the forming ecological networks in areas devastated by mining (Lipský 2007). It seems that current trends of recultivation of mining areas are mostly directed in favor of leaving these areas to the natural succession (Prach 2009).

The project of the actual (i.e. not only administrative) integration of the Tovačov Lakes into the Natura 2000 network will continue to support the mining company with planning of possible uses of the lake region for some ecological education activities such as nature trail and ornithological hides for bird-watching (Blaštíková 2007).

\section{ACKNOWLEDGEMENTS}

We'd like to thank to Mgr. Petr Zifčák for his help with the preparation of map analyses of the area of study. 


\section{REFERENCES}

Aronson, J., van Andel, J. (2006). Restoration Ecology: The new frontier. Blackwell Publishing, Oxford.

Blaštíková, K. (2007). Návrh naučné stezky v lokalitě Tovačovských jezer na Přerovsku. Diplomová práce, Univerzita Palackého, Olomouc.

Boháč, Z. (1975). Historická geografie. Ústav československých a světových dějin ČSAV, Praha.

Buček, A., Maděra, P., Kovářová, P. \& Pavlíková, T. (2002). Přežívání dřevin na zaplavených plochách př́rodní rezervace Věstonická nádrž. Výzkumná zpráva pro AOPK ČR, Ústav lesnické botaniky, dendrologie a typologie LDF MZLU v Brně MZLU, Brno.

Buček, A., Maděra, P. \& Packová, P. (2004). Hodnocení a predikce vývoje geobiocenóz v PR Věstonická nádrž. Geobiocenologické spisy, sv. 8, MZLU, Brno.

Buček, A., Maděra, P. \& Úradníček, L. (2007). Ecological network creation in the Czech Republic. In: Dreslerova, J. (Ed.) Ekologie krajiny - Journal of Landscape Ecology Vol.0, No.0, Brno: 12-24.

Cílek, V. (1999). Revitalizace lomů - principy a návrh metodiky. Ochrana př́rody 54: 7376.

Culek, M. (1996). Biogeografické členěni České republiky. Enigma, Praha.

Darby, S., Sear, D. (2008). River Restoration. Managing the Uncertainty in Restoring Physical Habitat. Joh Willey \& Sons, Hoboken.

De Moral, R., Walker, L.R. (2007). Environmental Disasters, Natural Recovery and Human Responses. Cambridge University Press, Cambridge.

Eiseltová, M., Pokorný, J., Ripl, W., Bodlák, L., Pechar, L., Pecharová, E. \& Kučera, Z. (2007). Restoration of water and matter retention functions of a floodplain: ecology and economics. In: Trémolieres, M., Schnitzler, A. (Eds.) Floodplain Protection, Restoration, Management. Why and how. 190-199. Paris: Lavoisier SAS

Guth, J. (2002). Metodika mapováni biotopů soustavy Natura 2000 a Smaragd. 3.vyd. Agentura ochrany př́rody a krajiny ČR, Praha.

Chuman, T. (2007). Těžební tvary v krajině jako objekt ochrany přírody. In: Grohmanova, L. (Ed.), Ekologie krajiny $\check{C} R$ - Těžba nerostných surovin a ochrana prírody. 85-94 pp. Sborník z konference CZ IALE, Brno

Hobbs, R.J., Harris, J.A. (2001). Restoration ecology: repairing the Earth's damaged ecosystems in the new millennium. Restoration Ecology, 9: 239-246.

Just, T., Šámal, V., Dušek, M., Fischer, D., Karlík, P. \& Pykal, J. (2003). Revitalizace vodního prostředí. Agentura ochrany prŕrody a krajiny ČR, Praha.

Klimo, E., Hager, H., Matić, S., Anić, I., Kulhavý, J. (2008). Floodplain Forests of the Temperate Zone of Europe. Lesnická práce, Kostelec nad Černými lesy.

Kolár̆, J. (1996). Land Cover Mapping using Remote Sensing and GIS Technology. In: Konečný, M. (Ed.) Conference GIS Frontiers on Business and Science, II, 31-49 pp.. GIS Series, Masaryk University, Brno

Kuchař, K. (1967). Mapové prameny ke geografii Československa. Acta Universitatis Carolinae - Geographica 2, Praha. 
Lillesand, T. M., Kieffer, R. W. (1995). Remote sensing and image interpretation. New York, Chichester, Brisbane, Toronto, Singapure: John Wiley \& Sons.

Lipský, Z. (2000). Sledování změn v kulturní krajině. Česká zemědělská univerzita, Praha.

Lipský, Z. (2007). Rekultivace Kopistské výsypky: vznik regionálního biocentra v devastované krajině. In: Grohmanova, L. (Ed.), Ekologie krajiny $\check{C} R-$ Těžba nerostných surovin a ochrana prírody. 119-128 pp. Sborník z konference CZ IALE, Brno

Lipský, Z. (2008). Změny ve využívání krajiny v údolních nivách. In: Pithart, D., Benedová, Z., Křováková, K. (Eds.), Ekosystémové služby údolní nivy. 132-141 pp. Ústav systémové biologie a ekologie, Třeboň

Löw, J., Míchal, I. (2003). Krajinný ráz. Lesnická práce, Kostelec nad Černými lesy.

Maděra, P. (2003). Proměny geobiocenóz lužního lesa. Habilitační práce, LDF MZLU Brno.

Machar, I., Bezděčka, P., Bureš, S., Kostkan, V., Loyka, P., Tlusták, V. \& Vermouzek, Z. (2007). Krajinně-ekologická studie Tovačovských jezer. Nepublikovaná zpráva pro Českomoravský štěrkopísek, a.s.Mokrá u Brna.

Maitland, P.S., Morgan, N.C. (1997). Conservation Management of Freshwater Habitats Lakes, Rivers and Wetlands. Chapman \& Hall. London.

Malanson, G.P. (1993). Riparian landscapes. Cambridge University Presss, Cambridge.

Miko, L., Borovičková, H., Havelková, S., Roth, P., Stloukal, P. \& Vopálková, A. (2005). Zákon o ochraně prírody a krajiny: komentářr. C.H.Beck, Praha.

Míchal, I., Petříček, V. (1998). Péče o chráněná území II. Agentura ochrany př́rody a krajiny ČR, Praha.

Míchal, I., Buček, A., Hudec, K., Lacina, J., Macků, J. \& Šindelář, J. (1992). Obnova ekologické stability lesů. Academia, Praha.

Muhar, S., Schmutz, S. \& Jungwirth, M. (1995). River restoration concepts - goals and perspectives. Hydrobiologia 303: 183-194.

Packalén, P., Maltamo, M., Tokola, T. (2008). Detailed assessment Using Remote sensing Techniques. In: Gadow, K., Pukkala, T. (Eds.), Designing Green Landscapes: 53-77.

Pechanec, V. (2006). Nástroje podpory rozhodování v GIS. Vydavatelství Univerzity Palackého v Olomouci.

Petts, G.E., Möller, H., Roux A.L. (1989). Historical Change of Large Alluvial Rivers: Western Europe. John Willey \& Sons, Chicester.

Prach, K. (2008). Ekologie obnovy (restoration ecology) jako mladý vědní obor a jeho stav v České republice. In: Devetter, M., Zemanova, K. (Eds.), Ekologie ve 21. století, 65 p. Sborník z konference ČSE, Třeboň

Prach, K. (2009a). Vztah krajinné a restaurační ekologie. In: Romportl, D., Chuman, T. (Eds.), Geo/bio diverzita - integrujici perspektivy. 36 p. Sborník příspěvků z výroční konference CZ IALE, Univerzita Karlova, Praha

Prach, K. (2009b). Ekologie obnovy narušených míst. I.Obecné principy. Živa 1/2009: 2224.

Prax, A., Richter, W., Čermák, J. \& Hybler, V. (2008). The hydrological and moisture regime of soils in floodplain forests. In: Klimo, E., Hager, H., Matić, S., Anić, I., Kulhavý, J. (Eds.), Floodplain Forests of the Temperate Zone of Europe. 75-101 pp. Lesnická práce, Kostelec nad Černými lesy 
Quitt, E. (1971). Klimatické oblasti Československa. Studia Geographica 16, Brno.

Ripl, W., Pokorný, J., Eiseltová, M. \& Ridgill, S. (1994). A holistic approach to the structure and function of wetlands and their degradation. In: Eiseltova, M. (Ed.), Restoration of Lake Ecosystem - a holistic approach. 16-35 pp. IWRB Publishing, Gloucester

Roth, P. (2009). Natura 2000 in the Czech republic: an approach leading to unplanned test of EU nature directives. In: Book of abstracts, $2^{\text {nd }}$ Euroean Congress of Conservation Biology, 37 p. Prague

Servus, M., Zifč́k, P. (2007). Historie oblasti Tovačovských jezer. Nepublikovaná zpráva pro Českomoravský štěrkopísek, a.s.Mokrá u Brna.

Servus, M., Machar, I. \& Zifčák, P. (2008). Plán obnovy biotopů a péče o území navrhované Přirodní památky Tovačovská jezera. Nepublikovaná zpráva pro Českomoravský štěrkopísek, a.s.Mokrá u Brna.

Siebel, H.N. (1998). Floodplain Forest Restoration. Alterra, Wageningen.

Simon, J., Buček, A., Vacek, S., Minx, T., Mikeska, M., Víteček, P., Müller, Š. \& Čížek, J. (2008). Tvorba lesního regionálního biocentra na zemédělské půdě. MZLU, Brno.

Sládek, S., Vokř́lová, K. (2006). Historická struktura krajiny jako podklad pro revitalizaci krajiny Vysokých Tater postižených kalamitou. Studie Fakulty živ. prostředí UJEP Ústí nad Labem pro MŽP ČR.

Stejskal, V. (2006). Úvod do právní úpravy ochrany př́rody a péče o biologickou rozmanitost. Linde, Praha.

Šafář, J. (2003). Chráněná území ČR-Olomoucko, svazek VI., Agentura ochrany př́rody a krajiny ČR, Praha.

Št’erba, O., Měkotová, J., Bednář, V., Šarapatka, B., Rychnovská, M., Kubíček, F. \& Řehořek, V. (2008). Řiční krajina a její ekosystémy. Univerzita Palackého,Olomouc.

Trémolliéres, M., Schnitzler, A. (2007). Floodplain Protection, Restoration, Management. Why and how? Lavoisier, Paris.

Vitousek, P.M., Mooney, H.A., Lubchenco, J. \& Melillo, J. (1997). Human domination of Earth's ecosystems. Science, 277: 494-499.

Walker, L.R., Walker, J. \& Hobbs, R. (2007). Linking Restoration and Ecological Succession. Springer, New York.

Ward, J.V., Tockner, K. (2001). Biodiversity: towards a unifying theme for river ecology. Freshwater Biology 46: 807-819. 